\title{
Isı Transfer Silindirlerinde Halka Akış Kanalı Geometrisinin Isıl Performansa Etkisinin Sayısal Olarak İncelenmesi
}

\author{
Ahmet Yurtseven ${ }^{1 *}$ \\ 1*Yıldız Teknik Üniversitesi, Gemi İnş. ve Den. Fak., Gemi Mak. İşletme Müh. Bölümü, İstanbul, Türkiye, (ORCID: 0000-0003-2561-1783), ahmety@ yildiz.edu.tr
}

(İlk GelişTarihi 22 Şubat 2021 ve Kabul Tarihi 06 Nisan 2021)

(DOI: 10.31590/ejosat.884809)

\begin{abstract}
ATIF/REFERENCE: Yurtseven, A. (2021). Isı Transfer Silindirlerinde Halka Akış Kanalı Geometrisinin Isıl Performansa Etkisinin Sayısal Olarak İncelenmesi. Avrupa Bilim ve Teknoloji Dergisi, (23), 552-562.

$\ddot{\mathbf{O} z}$

Bu çalışmada bir döner halka akım alanındaki 1sı transferi davranışı hesaplamalı akışkanlar dinamiği yardımıyla incelenmiştir. Çalışmaya konu olan halka akım alanı, endüstrinin farklı alanlarında yaygın olarak kullanılan ısı transfer silindirleri(merdane)'dir. Isı transfer merdanelerinde 1 sıtma ya da soğutma görevi, merdane yüzeyi altındaki halka kesitteki akım alanında hareket eden iş akışkanı ile sağlanır. Kanal geometrisi tarafından şartlandırılan iş akışkanının davranışı, 1sı transfer merdanesinin ısıl performansı ile doğrudan ilişkilidir. Bu çalışmanın amacı, iş akışkanının hareket ettiği kanalların geometrik yapısının 1sı transfer davranışına etkisinin araştırılmasıdır. Bu amaçla, endüstriyel uygulamalarda sıklıkla kullanılan ısı transfer merdanelerinin içerdiği iş akışkanı çalışma kanalı tipleri incelenmiş ve farklı tiplerde modeller belirlenerek sayısal olarak modellenmiştir. Çalışmada merdane dönüş hızı sabit tutulmuş ve üç farklı akışkan debisi incelenmiştir. Çalışma sonuçları toplam ısı transferi, roller yüzeyi sıcaklık dağılımı, üretilen malzemeden çekilen 1sı miktarı ve akışkanın hidrolik basınç düşüşü yönünden incelenmiştir. Çalışma sonucunda, iş akışkanını hidrodinamik olarak şartlandıran kanal geometrilerinin ısı transfer davranışı üzerinde önemli etkisi olduğu görülmüştür. Farklı akışkan kanalı yapılarına sahip merdane modellerinin değişen çalışma şartlarındaki isıl performansları karşılaştırmalı olarak irdelenmiş ve azalan spiralli kanallar içeren modelin uniform bir yüzey sıcaklığı eldesi yönünden fayda sağladığı görülmüştür.
\end{abstract}

Anahtar Kelimeler: Hesaplamalı akışkanlar dinamiği, merdane, 1sı transfer performansı, sayısal çözüm, azalan spiral.

\section{The numerical investigation of the effect of annular flow channel geometry on thermal performance in heat transfer cylinders}

\begin{abstract}
In this study, heat transfer behavior in a rotating annular flow field is investigated via computational fluid dynamics. The annular flow field subject to the study is the heat transfer cylinders (rolls) widely used in different fields of industry. The heating or cooling function in heat transfer rollers is provided by the work fluid moving in the flow area in the annular section under the roller surface. The behavior of the working fluid conditioned by the channel geometry is directly related to the thermal performance of the heat transfer roller. The purpose of this study is to investigate the effect of the geometric structure of the channels through which the work fluid moves on the heat transfer behavior. For this purpose, the types of work fluid working channels included in the heat transfer rollers, which are frequently used in industrial applications, were examined and models of different types were determined and modeled numerically. In the study, the roller rotation speed was kept constant and three different fluid flow rates were examined. The results of the study were examined in terms of total heat transfer, roller surface temperature distribution, the amount of heat absorbed from the produced material and the hydraulic pressure drop of the fluid. As a result of the study, it was seen that the channel geometries that hydrodynamically condition the working fluid have a significant effect on the heat transfer behavior. The thermal performances of roller models with different fluid channel structures under varying operating conditions have been comparatively examined and it has been observed that the model with decreasing spiral channels can benefit from a uniform surface temperature.
\end{abstract}

Keywords: Compututional fluid dynamics, roller, heat transfer performance, numerical solution, degressive spiral. 


\section{Giriş}

Eş merkezli dönen silindirler arasındaki halka akış alanında gerçekleşen akım alanı, diğer ismiyle Taylor-Couette akışı, G.I.Taylor'un öncü çalışmalarından bu yana akışkanlar mekaniğinin önemli araştırma alanlarından biri olmuştur. Halka akım kesitine eksenel akış da uygulandığında oldukça karmaşık bir akış alanı ortaya çıkar. Bu tarz akışlara mühendisliğin pek çok uygulamasında rastlanabilir. Gemilerdeki dizel motor krank şaft yatakları veya buhar türbinleri şaft yatakları, elektrik motorlarının soğutulması, petrol endüstrisindeki sondaj işlemi ve pek çok tipteki ayrıştırıcılar döner halka akış uygulamalarına örnek olarak gösterilebilir. Sözü edilen akış tipine ait hem ısı transferi içeren hem de içermeyen uygulamaların geniş bir derlemesi Cotrell ve Fénot tarafından sunulmuştur(Cotrell, 2003,

2. Fénot ve ark., 2011).

Döner halka akışların ısı transferi davranışı, klasik boru ya da kanal tipi iç akışlardan oldukça farklıdır. Akış alanını sınırlandıran silindirik duvarların dönüşü nedeniyle ortaya çıkan helisel tipteki akış yapısı, karışım, kütle transferi ve türbülansı, dolayısıyla da ısı transferini önemli ölçüde etkiler (Poncet ve ark., 2011, Huang ve Chun, 2003, Devisme ve ark., 2007, Lamberti ve Titomanlio, 2005). Bu nedenle döner halka akış alanlarının dinamiklerinin anlaşılması, ilgili mühendislik uygulamalarının performansının iyileştirilmesi açısından büyük öneme haizdir.

Döner halka akışların, pek çok endüstriyel uygulamada karşımıza çıkan özelleşmiş bir biçimi de, bu çalışmanın konusu olan 1S1 transfer merdaneleridir. Is1 transfer merdaneleri(silindirleri); plastik, ambalaj, tekstil, bask1 ve laminasyon gibi pek çok sektörde 1sı transfer silindiri olarak çalışır ve üretim sürecinin önemli bir parçasıdır. Merdaneler boşta dönerek ürünü taşımak, baskı ile malzeme kalınlığ oluşturmak veya malzemenin sıcaklığını artırmak ya da azaltmak amacıyla çalıştırılan farklı türlere sahiptirler. Pek çok sektörde kullanılan üretim yönteminde, işlenen malzeme bir üretim ağzından dökülerek baskı-şekillendirmemerdanelerinden geçip, arka arkaya sıralı soğutma merdanelerinde soğutulur(Devisme ve ark., 2007). Bu esnada, sıvalaşmış malzemenin istenilen forma sokulması ya da kalitesinin artırılması gibi işlemlerde sıcaklık kontrolü büyük öneme sahiptir(Lamberti ve Titomanlio, 2005). $\mathrm{Bu}$ nedenle isı transfer merdanelerinin performansinın iyileştirilmesi, yukarıda bahsi geçen ilgili sektörlerdeki üretim süreçleri açısından önem arz eder.

Merdanelerin üzerinde işleme tabi tutulan malzeme ile merdane yüzeyi arasındaki sıcaklık farkı dolayısıyla bir 1S1 transferi gerçekleşir. Kullanım amacına göre merdaneler ısıtıcı veya soğutucu olarak çalışabilir. Isıtıcı olarak çalışması durumunda merdanenin içinden geçen iş akışkanı merdaneyi soğutma görevi yapar. Soğutucu olarak çalışması durumunda ise 1S1 transferi tam tersi yönde gerçekleşir. Her iki çalışma durumunda da, 1sı transferini gerçekleştirmek amacıyla kullanılan iş akışkanı, merdane içindeki farklı geometrilere sahip kanalların içinde hareket eder ve şartlandırılır(Malewski, 1958, Sven, 1984, Theysohn, 1977, Wedel, 1984, Pato, 1968, Lockhar, 1967). Bu durum, iyi bilindiği gibi teknolojinin diğer alanlarında, örneğin buhar kazanları ve ısı değiştiricileri gibi sistemlerde de aynı şekildedir.

Merdane içindeki kanal geometrisi sistemin performansını ve geometrinin üretim zorluk derecesine bağlı olarak maliyeti de etkiler. Döner halka akışlarda, akım alanını sınırlandıran silindirik yüzeylerin geometrilerinin 1sıl performansa olan etkisi çeşitli çalışmalara konu olmuştur. Bu çalışmalarda, değişen akış yapısı nedeniyle 1sı transferi davranışının da etkilendiği ortaya konmuştur (Fénot ve ark., 2013, Jeng ve ark. 2007, NOuri ve Nakhchi, 2017). Halka akımın özelleşmiş bir türü olan 1s1 transfer merdanelerinde ise, akımın dış sınırında uniform sıcaklık gereksinimi gibi önemli bir farklılık bulunmaktadır. Plastik, ambalaj, tekstil, baskı ve laminasyon gibi endüstriyel alanlarda merdane üzerinden geçen malzemenin sıcaklığının homojen ve sabit olması gerekir. Malzemenin gerek kalınlık gerekse yüzey kalitesi, malzeme üzerinde oluşan isıl gerilmeler ile ilişkilidir ve malzemeye etkiyen gerilmenin miktarı sıcaklıktan doğrudan etkilenmektedir(Lu ve Pagilla, 2014). Yüzey sıcaklığı ise, merdane içerisindeki kanal geometrisi ve çalışan akışkanın hareketi ile ilişkili olduğundan, 1S1 transfer merdanelerindeki halka akış kanalı geometrileri ile 1 sıl performans arasındaki ilişki incelenmesi gereken bir konudur.

Is1 transfer merdanelerinin 1sıl performans1, literatürdeki çeşitli çalışmalara konu olmuştur. Sayısal çalışmalarda genellikle merdanenin isıl performansından ziyade üretilen malzemenin üretim esnasındaki ısıl davranışlarına odaklanılmıştır(Liu ve ark., 2009). Yeni geliştirilen esnek ekran ve esnek elektronik malzeme üretim teknolojilerinde 1 s1 transfer merdanesi uygulamalarının yaygınlaşması, bu alanda sayısal çalışmaların önemini artırmıştır. Çalışmalarda üretilen esnek malzemelerin ısıl ve mekanik yüklemelere göre gerilme davranışları incelenmiştir(Lu ve Pagilla, 2012). Kompozit malzemelerin üretiminde 1sıtma ve soğutma merdaneler ile gerçekleştirilir ve bu üretim sırasındaki 1sıl davranışın modellenmesi önem taşımaktadır. Ancak bu modellemelerde de isıtma ve soğutma etkisinin üretim malzemesi üzerindeki gerilim etkilerine odaklanılmıştır(Lu ve Pagilla, 2014). Yapılan deneysel çalışmada 1s1 transferi ile üretim malzemesinin merdane yüzeyine tutunma davranışındaki değişiklikleraraştırılmıştır(Jones ve ark., 2011). Literatürdeki mevcut çalışmalar incelendiğinde 1sıtma-soğutma işlemini sağlayan merdanelerdeki yapısal farklılıkların 1sıl performansa etkisinden ziyade, 1S1 transferi sonrası üretim malzemesinin davranışlarının incelendiği görülmektedir. Merdanenin 1S1 transfer mekanizmalarında film tabakasının ve merdane yüzeyinin ısıl sınır şartları değiştirilerek incelemeler yapılan çalışmalar da mevcuttur. Üniform sıcaklık, yığın ısı ve yayılı sıcaklık sınır şartlarının film tabakası ve merdane yüzey sıcakları üzerine etkileri incelenmiştir(Kumpinsky, 1993).

Literatürdeki mevcut çalışmalarda, 1Sı transfer merdaneleri sıklıkla iki boyutlu geometriler ile modellenmiş, temel boyutlar ve çalışma şartlarına göre performansları incelenmiştir. Merdanelerde ana boyutlar haricinde 1sıl performansı belirleyen merdane içi boyutlar ve isıl etkilere yer verilmemiştir. Çalışmalarda sıklıkla yüzeyde işlenen malzemenin davranışlarına odaklanılmıştır. Ancak merdane performansının ana unsuru olan hareket ettiği kanalın geometrisi tarafından şartlandırılan iş akışkanın isıl performansına etkisi halen incelenmesi gereken bir konudur. İç yapıdaki farklı tasarım ve boyutların ısıl etki oluşturan iş akışkanının davranışları üzerine önemli bir etkide bulunacağı bilinmektedir.

$\mathrm{Bu}$ çalışmada, farklı tipte iş akışkanı kanallarına sahip 1sı transfer merdanelerinde, akış yapısı ve 1sıl performansın değişimi hesaplamalı akışkanlar dinamiği kullanılarak incelenmiştir. $\mathrm{Bu}$ kapsamda, merdanelerin iş akışlarının bulunduğu ve ısıl performansın ana unsuru olan iç yapısında farklı geometrilere ve akış kanalı tiplerine sahip 7 farklı 1sı 
transfer merdanesi modeli içerisindeki akışkan akımı ve 1S1 transferi davranışı, sayısal olarak modellenmiş, sonuçlar karşılaştırmalı olarak sunulmuştur. Sayısal modelleme literatürdeki çalışmalara göre ilk kez üç boyutlu, zamana bağlı ve sistemli geometrik varyasyonlar halinde yapılmıştır. Sonuçlar farklı akış debileri için 1sı transfer miktarları, yüzey sıcaklık dağılımları, üretilen malzemeden çekilen 1sı ve basınç düşüşleri yönünden incelenmiştir.

\subsection{Isı transfer merdanelerin çalışması ve ısıl davranışı}

Isı transfer merdaneleri, üzerine dökülen ergimiş plastik benzeri eriyik malzemenin homojen olarak soğutulması için kullanılır. Genel olarak üretilen malzeme merdane yüzeyinin belirli bir bölümüne sarılarak o bölgeden 1s1 çekilir ve merdanenin dönüş hızına bağlı olarak soğuyan plastik malzeme üretim hattında ileri aktarılır.

Şekil 1'de genel bir 1sı transfer merdanesinin çalışma şekli görülmektedir. Merdanenin belirli bir açıda yüzeyine sarılan ergimiş malzemenin 1sısı öncelikle merdanenin dış cidarına devamında dış cidarın altında bulunaniş akışkanına aktarılır. Birim zamanda iş akışkanına aktarılan 1sı miktarı, merdane yüzeyinde işlenen materyal miktarına, merdane dönüş hızına ve merdane geometrisine göre değişmektedir.

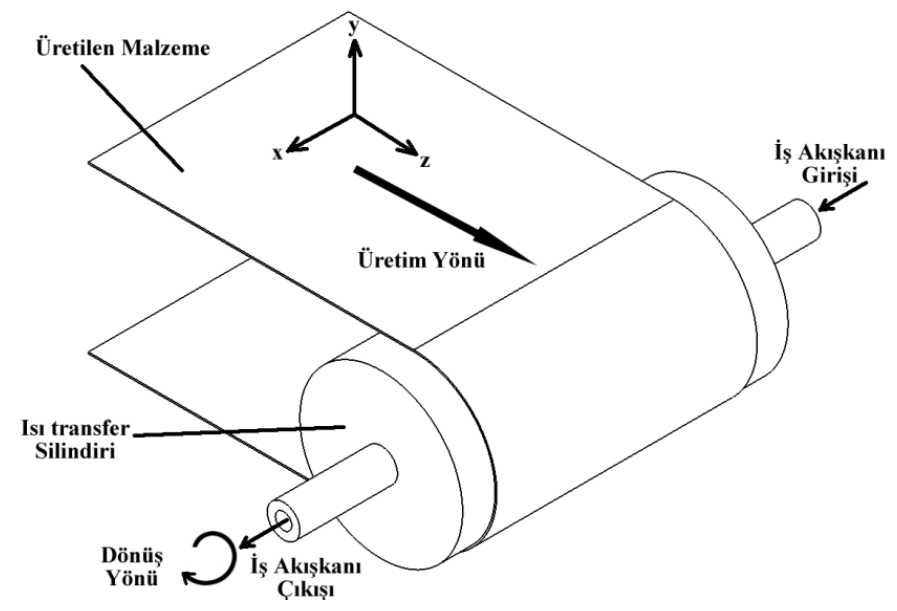

Şekil 1: Isı transfer merdanesinin(silindir) çalışması

Isı transfer merdanelerinin kullanıldığı üretim süreçlerinde önem arz eden konulardan biri de üretilen malzemenin her bölgesinden eşit miktarda 1S1 transfer edilerek, 1Sıl gerilim sonucu oluşacak herhangi bir üretim hatasının önüne geçilmesidir. $\mathrm{Bu}$ gereksinimin sağlanması için en temel parametre, merdane yüzeyindeki boyuna sıcaklık dağılımıdır. Isı transfer merdanesinde ideal çalışma şartları, 1sı transferi esnasında merdane dış yüzeyinde homojene yakın sıcaklık dağılımının elde edilmesi ile sağlanır. Homojen sıcaklık dağılımı elde edebilmek için önemli faktörlerden birisi de diş cidarın altındaki iç kanal tasarımıdır. İç kanalda iş akışkanı hidrodinamik olarak şartlandırıldığ 1 için ısı transferi ve akışkanın merdane boyunca sıcaklık değişimi önemli oranda etkilenmektedir.

Merdanelerin kullanıldı̆̆ı endüstriyel uygulamalarda, merdane yüzeyinin sıcaklık kontrolü için, iş akışkanının hareket edeceği kanallar farklı tiplerde olabilmektedir. Bu kanal tiplerinin seçiminde de, maliyet, üretim kolaylığı, gerek duyulan pompa gücü gibi pek çok parametre etkili olur. Bunlardan yapısal olarak en basit olanı iş akışkanının içi boş bir merdanede serbest olarak hareket ettirilmesidir. Bu tip merdanelerde çok miktarda 1sı transfer akışkanının merdane içerisine alınması gerekmektedir. $\mathrm{Bu}$ durum merdanenin çalışma ağırlığını artırmakta, mukavemet ve yataklama problemlerine neden olabilmektedir. Ayrıca, merdane içerisinde hareket eden akışkanın büyük bir kısmı merdane iç yüzeyi (1sı transfer yüzeyi) ile temas etmeyeceği için 1sı transfer etkinliğini konusunda verimi düşüktür. Bu sebeplerden dolayı hem kullanılan akışkan miktarını azaltmak hem de dolaşaniş akışkanının 1sı transfer etkinliğini artırmak için merdane içyapısında bazı yapısal değişikliklere gidilmektedir. Yapılan farklı uygulamaların kendilerine özgü avantaj ve dezavantajları vardır.

Merdane, iç mimarisine eklenen yapılar ile genel olarak bir halka akış bölgesioluşturur. İş akışkanı, merdane dış cidarı ve içe eklenen ikinci bir silindirik yapının cidarı arasında meydana gelen bu halka akış bölgesi içerisinde hareket eder. Ancak bu sistemin de zorluğu, halka akış bölgesi içerisinintamamında dengeli bir akışkan hızısağlamaktır. Çünkü soğutma bölgesinde çalışan akışkanda gözlenen hız farklılıkları 1sı transfer etkinliğinde, dolayısıyla da merdane yüzey sıcaklığında uniform olmayan sonuçlaraneden olur. $\mathrm{Bu}$ problemi azaltmak için kullanılan yöntemlerden birisi halka akış bölgesini boyuna parçalara ayırmaktır. Bu sayede akışkan geniş bir kesitteki halka akış yerine kanal akışı davranışı gösterir ve boş bir halka akış bölgesine göre çok daha şartlandırılmış bir akış hareketi elde edilir. Genellikle spiral bir yol izleyen bu kanalların genişlikleri ve hatve yapısı, uygulamaya göre sabit ya da değişken olabilmektedir.

Kanalların helisel hatvesinin ve kesitinin sabit olduğu durumda iş akışkanı girişten çıkışa doğru sabit bir hız ile ilerlemektedir. Kesit alanının sabit olması dolayısıyla taşınım katsayısı akış boyunca değişmeyecektir. Ancak iş akışkanı üretilen malzemeden sürekli olarak 1sı çektiği için sıcaklığ çıkışa doğru artacaktır. $\mathrm{Bu}$ durumda, girişten çıkışa doğru hareket ettikçe üretilen malzeme ile iş akışkanı arasında sıcaklık farkı azalır ve akışkandan yüzeye olan 1sı transfer miktarı çıkış bölgesine doğru değişecektir.

Isı transfer merdanesinin yüzey sıcaklığını dengeli bir yapıda tutmak, diğer bir deyişle üretilen malzemenin sıcaklığını dengeli şekilde azaltmak ya da artırmak için malzemeden dengeli şekilde bir 1sı transferi gerçekleştirilmelidir. Çalışan akışkanın merdane boyunca hareketi esnasında düzenli olarak ısı çektiği göz önünde bulundurulursa, 1Sı taşınım katsayısının da akım boyunca artırılması, sabit 1sı transfer miktarı sağlama adına fayda sağlayabilir. Isı taşınım katsayısı doğrudan akışkan hızına bağlı olduğu için, kanal içerisindeki helisel kanallar boyunca hareket eden akışkanın girişten çıkışa doğru hızının artırılması ısıl taşınım katsayısının da artmasını sağlar. $\mathrm{Bu}$ noktadan hareketle, iş akışkanının çalıştığı kanalların kesit alanının çıkış bölgesine doğru gidildikçe azaltılması, kütle korunumu dolayısıyla akış hızının, aynı zamanda da taşınım katsayısının akış boyunca artırılmasını ve sabit bir ısı transfer miktarı elde edilmesini sağlayabilir. Helisel doğrultudaki kesitin azaltılması için kullanılan helisin hatvesinin çıkış kenarına doğru azaltılması önemli ve gereklidir.

Merdanelerde kullanılan kanal geometrilerinde, is akışkanının şartlandırılması açısından önem arz eden bir diğer özellik de, akışkanın merdaneye giriş ve çıkışı ile ilgilidir. Akışkan merdaneye bir yönden girip, 1S1 transferini gerçekleştirdikten sonra karşıt yönden çıkabilir. Bu tarz merdane tasarımları tek akışlı (MF) merdane olarak anılır. Eğer iş 
akışkanı merdaneyi, eş merkezli kanallar vasıtasıyla girdiği koldan terk ediyorsa bu tip merdaneye de çift akışlı (DF) merdane ismi verilir.

\section{Materyal ve Metot}

Çalışmada farklı kanal geometrilerine sahip 1sı transfer merdaneleri içerisindeki akış alanı ve 1Sı transferi davranışı hesaplamalı akışkanlar dinamiği kullanılarak incelenmiştir. Çalışmanın matematiksel ve sayısal ayrıntıları ve kullanılan geometrilerin özellikleri aşağıdaki bölümde sunulmaktadır.

\subsection{Geometri ve akış şartları}

Çalışmadaki çözüm alanını oluşturan merdane geometrisi Şekil 2'de görülmektedir. Akışkan giriş ve çıkış kanalları aynı boyutlara sahiptir. Merdaneyi oluşturan silindirin altında, iş akışkanının hareket ettiği kanalı oluşturan eşmerkezli bir iç silindir daha bulunmaktadır. Akışkan bu iki silindirin oluşturduğu halka bölgede hareket etmektedir. Çözülen tüm geometriler için bu kanalın genişliği $\mathrm{t}_{\mathrm{kanal}}=15 \mathrm{~mm}$ 'dir. Merdane geometrisine ait diğer boyutlar Tablo 1'de verilmiştir.

Tablo 1: Merdane boyut ayrintılarl

\begin{tabular}{c|c}
\hline Semboller & Boyutlar $[\mathbf{m m}]$ \\
\hline $\mathrm{L}_{\text {silindir }}$ & 1600 \\
\hline $\mathrm{L}_{\text {silindir yüzeyi }}$ & 1000 \\
\hline $\mathrm{L}_{\text {üretilen malzeme }}$ & 800 \\
\hline $\mathrm{D}_{\text {silindir }}$ & 500 \\
\hline
\end{tabular}

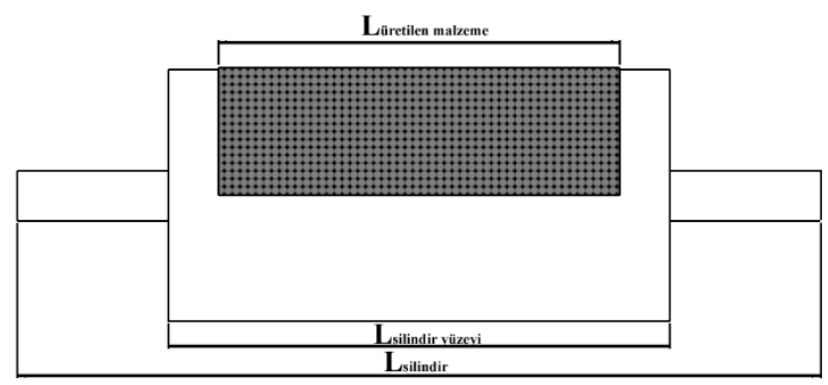

\begin{tabular}{c|c}
\hline $\mathrm{D}_{\text {kol }}$ & 100 \\
\hline $\mathrm{D}_{\text {giriş/çıkış }}$ & 50 \\
\hline $\mathrm{t}_{\text {kabuk }}$ & 5 \\
\hline $\mathrm{t}_{\text {kanal }}$ & 15 \\
\hline$\alpha$ & $180^{\circ}$ \\
\hline
\end{tabular}

$\mathrm{Bu}$ çalışmada farklı akışkan kanallarına sahip merdane geometrilerinin sayısal çözümü gerçekleştirilmiştir. Bu modellerin ayrıntıları Şekil 3'te verilmiştir. Çözülen ilk geometride merdane içerisinde herhangi bir kanal bulunmamakta ve iş akışkanı kanalsız (Base) silindirik bölgede hareket etmektedir. Bu geometri çözülen diğer kanal tiplerinde yapılacak kıyaslamalar için kullanılmıştır. Diğer geometrideiş akışkanının hareketi, dış cidarın altında başka bir iç cidar ile kısıtlanarak meydana getirilen halkasal bir kanalda gerçekleşmektedir. $\mathrm{Bu}$ kanal tipine sahip geometriye çift cidarlı (DC) merdane ismi verilmiştir ve kanal içerisinde akışı şartlandıran herhangi bir engel bulunmamaktadır. Halka akış alanı içerisinde, akışın ısı transfer yüzeyi ile homojen biçimde etkileşime girmesini sağlayan spiral kanallar bulunan geometri sabit spiralli (CS) merdane olarak isimlendirilmiştir. Söz konusu geometride spiral kanallar sabit bir hatve ile oluşturulmuştur. Sabit hatvelispiralli modellerde iş akışkanın merdane boyuna hareketi esnasında 1sinmasi ve bu nedenle merdane boyuna 1s1 transferinin azalmasının engellenmesi amacıyla spiral kanalların kesitleri merdane çıkışına doğru daraltılarak oluşturulan tasarıma da azalan spiralli (DegS) merdane ismi verilmiştir. Base model hariç tüm kanal tipleri MF ve DF olarak çözülmüştür. Çalışmada test edilen geometriler Tablo 2'de özetlenmiştir. Geometrilerin isimlendirilmesi amaciyla kullanılan kısaltmalarda ilk kısım kanal yapısını, ikinci kısım ise akış tipini göstermektedir.

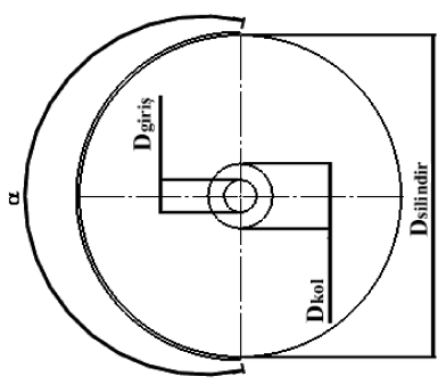

Şekil 2: Merdane temel boyutları

Tablo 2: Farkl geometrilerin özeti

\begin{tabular}{c|c|c}
\hline Geometri (Kanal tipi) & Kısaltma & Tanım \\
\hline Kanalsız & Base & Kanalsız tek silindir \\
\hline \multirow{2}{*}{ Halka kanal } & DC - MF & Halka kanal - Tek Akışlı \\
\cline { 2 - 3 } & DC - DF & Halka kanal - Çift Akışlı \\
\hline \multirow{2}{*}{ Sabit spiral } & $\mathrm{CS}-\mathrm{MF}$ & Sabit Spiralli Halka kanal - Çift \\
& & akışlı \\
\cline { 2 - 3 } & CS - DF & Azalan Spiralli Halka kanal - \\
\hline Azalan Spiral & DegS-MF & Tek \\
\hline
\end{tabular}




\begin{tabular}{c|c|c}
\hline \multirow{2}{*}{ DegS- DF } & Tek akışlı \\
\cline { 2 - 3 } & & Azalan Spiralli Halka kanal - \\
& Çift akışlı \\
\hline
\end{tabular}
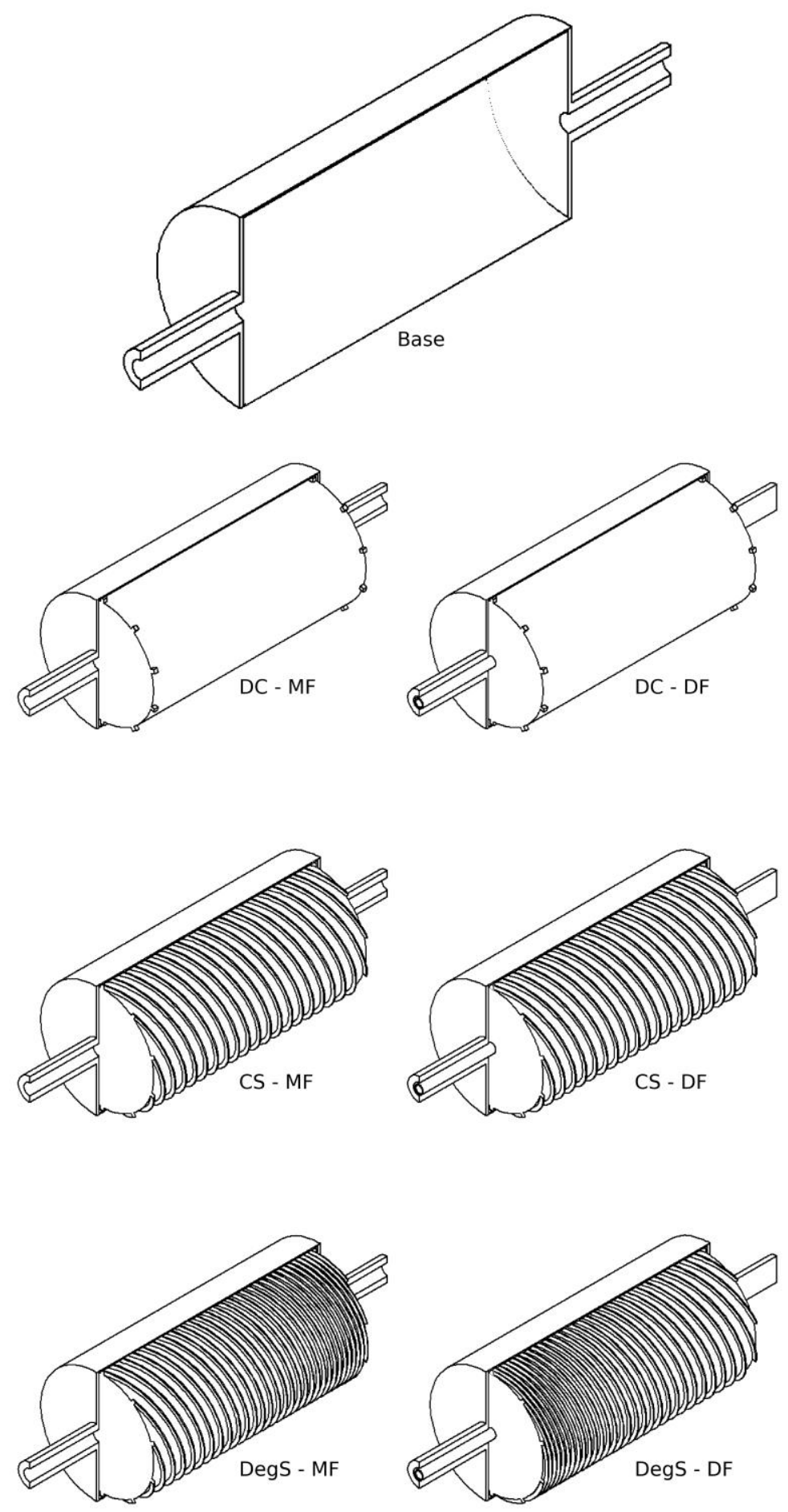

Şekil 3: Farklı iç tasarım türlerine göre farklı tiplerdeki merdaneler

Çalışma genelinde, merdane dönüş hızı $1 \mathrm{dev} / \mathrm{s}$ değerinde sabit tutulmuştur. İş akışkanı debisi için ise üç farklı değer $(100 \mathrm{~kg} / \mathrm{dk}$, $200 \mathrm{~kg} / \mathrm{dk}, 300 \mathrm{~kg} / \mathrm{dk}$ ) test edilerek, farklı kanal tiplerinin değişen akışkan debileri için performansı incelenmiş̧ir.
Viskoz, sıkıştırılamaz ve zamana bağlı akışkan akımını yöneten süreklilik ve hareket denklemleri aşağıda sırasıyla verilmiştir.

\subsection{Yönetici Denklemler}


$\frac{\partial \bar{U}_{i}}{\partial x_{i}}=0(1)$

$\rho\left(\frac{\partial U_{i}}{\partial t}+U_{j} \frac{\partial U_{i}}{\partial x_{j}}\right)=-\frac{\partial P}{\partial x_{i}}+\frac{\partial}{\partial x_{j}}\left(\mu \frac{\partial U_{i}}{\partial x_{j}}-\rho \overline{u_{i}^{\prime} u_{j}^{\prime}}\right)+\tilde{F}_{i}^{(2)}$

Burada $P$ basınç, $\quad U_{i}$ hız $\quad$ vektörü, $\rho$ yoğunluk, $\quad \mu$ dinamik viskozite ve $\tilde{F}_{i}$ dış kuvvetlerdir. Denklemin sağ tarafında bulunan $-\rho \overline{u_{i} u_{j}}$ terimi eddyviskozite yaklaşımı ile modellenen Reynolds gerilmeleridir:

$-\rho \overline{u_{i}^{\prime} u_{j}^{\prime}}=2 \mu_{\tau} S_{i j}-2 / 3 \rho k \delta_{i j}(3)$

Burada $k$ türbülans kinetik enerjisi $\quad$ ve $\mu_{\tau}$ türbülans viskozitesidir. Türbülans viskozitesi $k-\varepsilon$ türbülans modeli kullanılarak ortalama akış değişkenleri ile tanımlanır(Wilcox, 1998):

$\mu_{\tau}=\rho C_{\mu} k^{2} / \varepsilon$

Burada $\varepsilon$ türbülans yayılma oranıdır. Türbülans kinetik enerjisi ve yayılma oranı Eş. 5 ve Eş. 6'da verilmiştir(Shih ve ark., 1995, SiemensPLM, 2019).

$\frac{\partial}{\partial t}(\rho k)+\nabla \cdot(\rho k \overline{\mathrm{v}})=\nabla \cdot\left[\left(\mu+\frac{\mu_{t}}{\sigma_{k}}\right) \nabla k\right]+P_{k}$

$-\rho\left(\varepsilon-\varepsilon_{0}\right)+S_{k}$

$\frac{\partial}{\partial t}(\rho \varepsilon)+\nabla \cdot(\rho \varepsilon \overline{\mathrm{v}})=\nabla \cdot\left[\left(\mu+\frac{\mu_{t}}{\sigma_{\varepsilon}}\right) \nabla \varepsilon\right]$

$+\frac{1}{T_{\varepsilon}} C_{\varepsilon 1} P_{\varepsilon}-C_{\varepsilon 2} f_{2} \rho\left(\frac{\varepsilon}{T_{e}}-\frac{\varepsilon_{0}}{T_{0}}\right)+S_{\varepsilon}$

Diğer yönetici denklemleriyle birlikte, ısıl alanı modellemek için enerji denklemi aynı anda çözülür:

$\rho\left[\frac{\partial h}{\partial t}+\nabla \cdot(h \vec{V})\right]=-\frac{D p}{D t}+\nabla \cdot(k \nabla T)+\phi$

Burada $h$ özgül entalpiyi göstermektedir. Özgül entalpi $h=e+p / \rho . T$ şeklinde tanımlanır. $T$ mutlak sıcaklı̆̆ 1 ve $\phi$ ise yayılma fonksiyonudur.

\subsection{Problem tanımı ve sayısal konfigürasyon}

Çalışmada üç boyutlu, zamana bağlı, türbülanslı viskoz akış hesaplamalı akışkanlar dinamiği ile sayısal olarak çözülmüştür.Yönetici denklemler sonlu hacimler yaklaşımı ile ayrıklaştırılmıştır. Konumsal ayrıklaştırma için ikinci dereceden bir şema kullanılırken, zamansal ayrıklaştırma için birinci dereceden şema kullanılmıştır. Türbülans alanı Realizable k-
Etürbülans modeli ile elde edilmiştir. Tüm sayısal hesaplamalar Siemens SimCenter-Star CCM+ ticari kodu ile yapılmışıtır.

Oluşturulan sayısal modelde, merdane dış yüzeyi üzerine temas eden üretim malzemesi ve merdane içerisindeki kanallarda hareket eden iş akışkanı, metal merdane gövdesi üzerinden isı transferi gerçekleştirmektedir. $275^{\circ} \mathrm{C}$ sıcaklıktaki üretim malzemesi merdane dış yüzeyine $(\alpha): 180^{\circ}$ lik bir sarım açısı ile temas etmektedir. Kanal duvarlarına kaymama koşulutanımlanmış, teğetsel yön dışındaki hız bileşenleri sıfıra eşitlenmiştir. Merdane dış yüzeyi haricindeki tüm yüzeyler adyabatiktir. İş akışkanının giriş sınırına uniform akış hızı tanımlanmıştır. İş akışkanı çözüm alanına $25^{\circ} \mathrm{C}$ 'lik sabit sıcaklık ile girmekte ve merdane kanal yüzeyleri ile 1S1 transferi gerçekleştirmektedir. Çözüm alanını oluşturan materyallerin termo-fiziksel özellikleri Tablo 3’te verilmektedir.

Tablo 3: Çalışmada kullanılan malzemelerin termo-fiziksel özellikleri

\begin{tabular}{c|c|c|c}
\hline & $\begin{array}{c}\text { Üretim } \\
\text { Malzemesi }\end{array}$ & Gövde & $\begin{array}{c}\text { Iş } \\
\text { Akışkanı }\end{array}$ \\
\hline $\boldsymbol{\rho}\left[\mathbf{k g} / \mathbf{m}^{3}\right]$ & 1100.0 & 7832.0 & 997,6 \\
\hline$c_{\rho}[\mathrm{J} / \mathbf{k g}-\boldsymbol{K}]$ & 692.0 & 434.0 & 4181,7 \\
\hline $\boldsymbol{k}[\boldsymbol{W} / \mathbf{m}-\boldsymbol{K}]$ & 0.9 & 63.9 & 0.62 \\
\hline $\boldsymbol{\mu}[\boldsymbol{P a}-\mathbf{s}]$ & - & - & 0,000889 \\
\hline
\end{tabular}

\section{4.Çözüm Ăğ}

Çözüm alanı altı yüzlü yapısal çözüm ağı elemanları kullanılarak oluşturulmuştur. Çözüm ağı yapısının merdane dış yüzeyi ve orta kesiti için görünümü Şekil 4 'te verilmektedir. Yüksek hız ve ısıl gradyenleri yakalamak amaciyla ağ yapısı duvar yakınlarında inceltilmiş̧ir. Duvar üzerindeki ilk ağ elemanının yüksekliği, kullanılan duvar fonksiyonu yaklaşımının gereği olarak $y^{+}>30$ değerini sağlayacak şekilde yerleştirilmiştir $\left(y^{+}=u_{\tau} y / v\right.$, burada $u_{\tau}$ sürtünme hızı, $y$ ilk ap elemanının yüksekliği, $v$ kinematik viskozite).

Sayısal çözümlerin ağdan bağımsızlığını araştırmak adına ağ yapısı sistematik olarak inceltilmiş ve sonuçlar toplam isı transferi yönünden karşılaştırılmıştır. Farklı çözüm elemanı sayılarıyla gerçekleştirilen çözümlere ait sonuçlar Tablo 4'te görülmektedir. Hem doğruluk, hem de hesaplama zamanı gözetilerek, sayısal çözümlere Grid-2 ile devam edilmişsir.

Tablo 4: Çözüm ă̆ı bağımsızlık çalışması özeti

\begin{tabular}{c|c|c}
\hline Çözüm Ağı & Eleman Sayısı & Q (W) \\
\hline Grid-1 & 2464877 & 27654,2 \\
\hline Grid-2 & 1229070 & 27644,54 \\
\hline Grid-3 & 522679 & 27417,47 \\
\hline
\end{tabular}



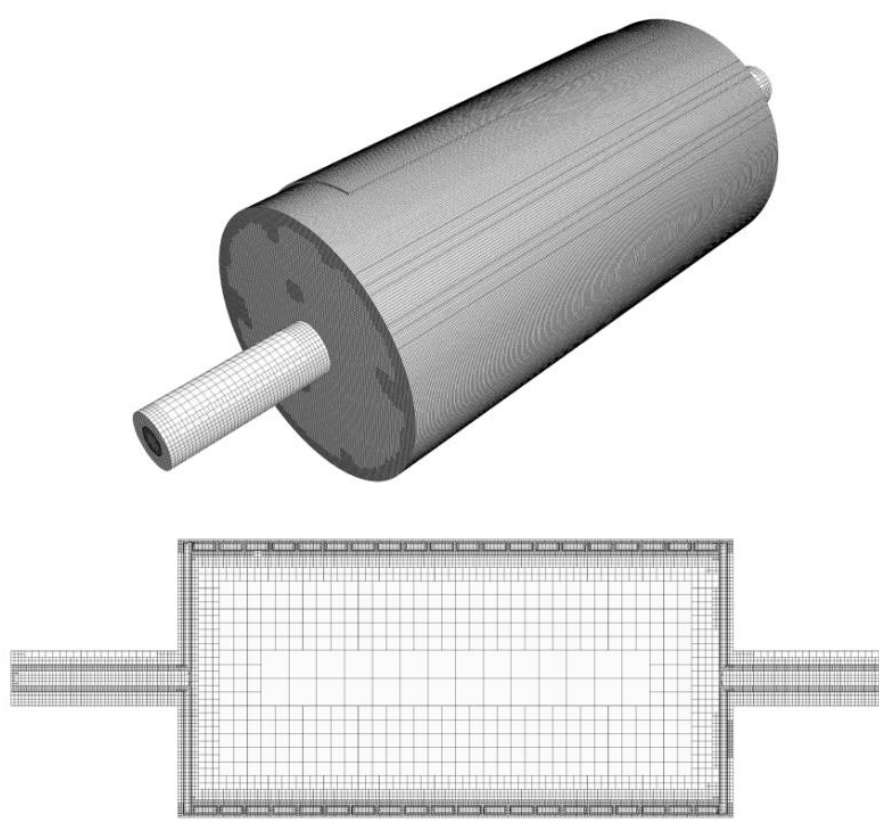

Şekil 4: Isı transfer merdanesi için kullanılan çözüm ağ

\subsection{Doğrulama Çalışması}

Yapılan kaynak araştırmasında 1sı transfer merdanelerindeki sayısal tahminleri doğrulamak için kullanılabilecek deneysel veri bulunamamıştır. Bu nedenle, sonuçların güvenilirliğini artırmak için hesaplamaların sayısal belirsizliği değerlendirilmiştir. Çözüm ağı tabanlı belirsizlik, Roache tarafindan önerilen Çözümağı Yakınsama Metodu (GridConvergence Index-GCI) kullanılarak tahmin edilmektedir(Boache, 1994). GCI yöntemi aynı zamanda Amerikan Havacılık ve Uzay Bilimleri Enstitüsü (AIAA) ve Amerikan Makine Mühendisleri Derneği (ASME) tarafından hesaplamalı akışkanlar dinamiği sonuçlarının sayısal belirsizliğini incelemek için önerilen yöntemdir(Rahaim ve ark., 2003). Yöntem, Richardsonekstrapolasyonuna dayanır ve sistematik olarak çözünürlüğü artırılmış çözüm ağı sonuçlarını kullanarak belirsizlik seviyelerini tahmin eder. Elde edilen GCI değeri, asimptotik sayısal değer ile hesaplanan değer arasındaki farklılığın bir ölçüsü olduğu için sayısal belirsizliği veya ayrıklaştırma hatasını gösterir. Belirsizlik değerlendirmesi, önceki bir çalışmada aşağıdaki gibi tanımlanmıştır(Celik ve ark. 2008).

İlk olarak metodun mertebesi ( $p$ ) Eş. 8'deki şekilde hesaplanır;

$$
p=\frac{1}{\ln \left(r_{21}\right)}|\ln | \varepsilon_{32} / \varepsilon_{21}|+q(p)|(8)
$$

$q(p)=\ln \left(\frac{r_{21}^{p}-s}{r_{32}^{p}-s}\right)$

$$
s=1 \cdot \operatorname{sgn}\left(\varepsilon_{32} / \varepsilon_{21}\right)(10)
$$

Burada $\varepsilon_{32}=\phi_{3}-\phi_{2}$ dir.

$\phi$ incelenen çözüm ağı yapısındaki sayısal sonucu, $r$ ise sıklaştırma oranını temsil eder. Ekstrapole edilmiş değerler şu şekilde hesaplanabilir; $\phi_{e x t}^{21}=\frac{r_{21}^{p} \phi_{1}-\phi_{2}}{r_{21}^{p}-1}(11)$

Yaklaşık bağıl hata $\left(e_{a}^{21}\right)$ ve ekstrapole edilmiş bağıl hata $\left(e_{e x t}^{21}\right)$ şu şekilde hesaplanabilir;

$e_{a}^{21}=\left|\frac{\phi_{1}-\phi_{2}}{\phi_{1}}\right|(12)$

$e_{\text {ext }}^{21}=\left|\frac{\phi_{\text {ext }}^{12}-\phi_{1}}{\phi_{\text {ext }}^{12}}\right|(13)$

Orta ve iyi çözünürlükteki çözüm ağlarının, ağ yakınsama indeksleri hesaplanabilir. Roache tarafından güvenlik faktörü $\mathrm{FS}=1,25$ olarak önerilmiştir(Roache, 1998). Farklı çözünürlükteki çözüm ağlarının GCI değerleri Eş. 14 ve Eş. 15 'deki şekilde hesaplanabilir.

$G C I_{\text {fine }}^{21}=\frac{1.25 e_{a}^{21}}{r_{21}^{p}-1}(14)$

$G C I_{\text {medium }}^{32}=\frac{1.25 e_{a}^{21} r_{21}^{p}}{r_{21}^{p}-1}(15)$

Doğrulama çalışmasının sonuçları Tablo5'te sunulmuştur.Toplam 1S1 akısı değerinin ayrıklaştırılmasından kaynaklanan belirsizliğin hem yüksek çözünürlüklü ağ hem de orta çözünürlüklü ağ için oldukça düşük olduğu görülmektedir. Hem hesaplama maliyeti hem de doğruluk dikkate alındığında, çalışmanın geri kalanında sayısal hesaplamalarda orta çözünürlüklü ağ kullanılır.

Table 5: Doğrulama çalışmasının özeti

\begin{tabular}{c|c}
\hline & $\mathrm{Q}$ \\
\hline$\phi_{1}$ & 27654,2 \\
\hline$\phi_{2}$ & 27631,1 \\
\hline$\phi_{3}$ & 27449,4 \\
\hline$p$ & 7,74 \\
\hline$\phi_{\text {ext }}^{21}$ & 27658,8 \\
\hline$e_{a}^{21}$ & 0,000837484 \\
\hline$G C I^{21}$ & $0.02 \%$ \\
\hline$G C I^{32}$ & $0,10 \%$ \\
\hline
\end{tabular}




\section{Araştırma Sonuçları ve Tartışma}

Farklı iç kanal yapısına sahip 7 farklı 1sı transfer silindiri geometrisi için toplam ısı transferi, sıcaklık dağılımı ve basınç düşüşü hesaplanan değerleri bu bölümde sunulmuştur.

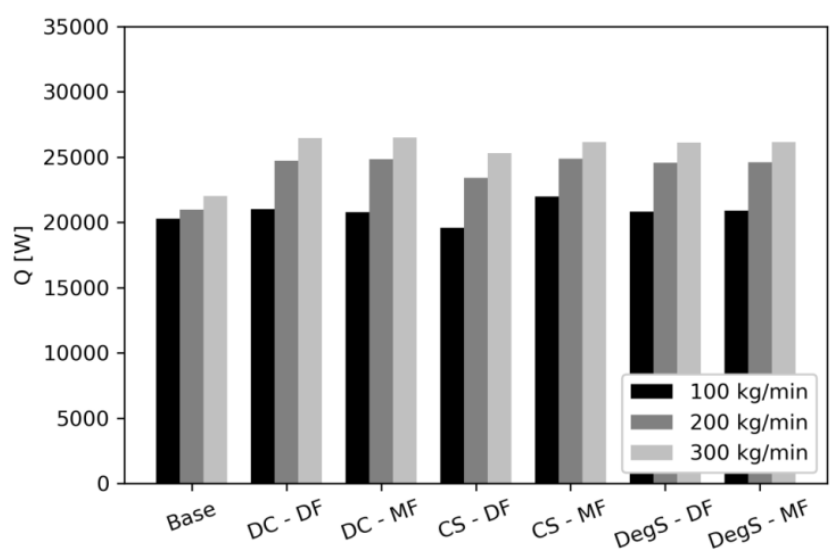

Şekil 5: Merdanelerin üretim malzemesinden çektikleri 1s1 transfer miktarları

Şekil 5 'de $100 \mathrm{~kg} / \mathrm{min}, 200 \mathrm{~kg} / \mathrm{min}$ ve $300 \mathrm{~kg} / \mathrm{min}$ olmak üzere üç farklı iş akışkanı debisi için üretim malzemesinden çekilen toplam 1S1 transfer miktarları verilmiştir. Kullanılan akışkan debisi 1sı transfer merdanelerinin işletme maliyeti ile doğrudan ilişkili olduğu için, farklı debilerdeki 1sı transfer etkinliğinin gözlenmesi endüstriyel uygulamalar açısından önemli bir konudur. Herhangi bir yapısal değişiklik ya da kanal içermeyen merdane geometrisi (Base) en düşük 1s1 transferini sağlamaktadır. "Base" modelde elde edilen 1s1 transfer miktarının iş akışkanı debisi ile değişimi de kısıtlıdır. Bu durum aynı miktar iş akışkanı kullanımı ile daha fazla 1sı transferi sağlamak için merdane yapısında değişikliğe gidilmesi ve iş akışkanının kanallar vasıtası ile kullanılmasının önemli olduğunu düşündürmektedir. Farklı kanal yapıları içeren modellerde ise iş akışkanı debisinin artması ile birlikte toplam ısı transferi de artmaktadır. İş akışkanı hareketinin tek akışlı (MF) ve çift akışlı (DF) şeklinde sağlanmasının aynı kanal tasarımı içerisinde toplam 1sı transferi üzerinde DC model hariç önemli bir etkisi olmadığı görülmektedir. Farklı kanal tasarımlarının 1sı transfer miktarına etkisi ise, düşük iş akışkanı debileri için daha belirgindir.

Farklı merdane geometrileri için, merdane yüzeyindeki sıcaklık değerlerinin akım yönündeki değişimi Şekil 6'da görülmektedir. s* merdane boyu ile boyutsuzlaştırılmış akış yönüdür. İş akışkanı debisi arttıkça, merdane yüzeyi boyunca sıcaklık değerlerinin azalma eğiliminde olduğu görülmektedir.Düşük debilerde (Şekil 7.a) "Base" modelde merdane yüzey sıcaklığının akışkan giriş ve çıkış noktaları arasındaki değişimi oldukça sınırlıdır. Ancak akışkan debisi arttıkça hem sıcaklık azaltımı sağlanamamakta, hem de sıcaklık dağılımının uniform yapısı bozulmaktadır. Merdanenin iki ucu arasındaki sıcaklık farkının en yüksek olduğu model boş halka akış kanalı içeren DC modelidir. Sıcaklık farkının bu denli yüksek oluşuna, bu geometrideki akış boyunca düşen 1sı transfer katsayısının neden olduğu düşünülmektedir. Yüzey sicaklığı yönünden en iyi dağılımın sabit spiral kanallar içeren CS model olduğu görülmektedir. Akışkan debisi arttıkça bu modelde de çıkış kenarına doğru az da olsa bir sıcaklık artışı görülmektedir. DegS modelinde özellikle yüksek iş akışkanı debilerinde çıkış kenarına doğru 1sı transfer katsayısı istenilenden fazla artmış ve sıcaklık çıkış ucuna yaklaştıkça azalmıştır.

Merdane yüzeyindeki sıcaklık dağılımlarının, farklı merdane modelleri için değişimi Şekil 7'de verilmiştir.

"Base" modeliniş akışkanı debisinin artışı ile yüzey sıcaklığındaki dengeyi kaybettiği görülmüştür. $\mathrm{Bu}$ durumun tersine tüm kanal tasarımlarında debinin artması ile yüzey sıcaklığı daha dengeli hale gelmiștir. Her bir iș akışkanı debisi için sonuçları kendi içlerinde incelediğimizde, yüzey sıcaklık dağılımının en fazla bozulduğu modelin DC modeller olduğu görülmüştür. CS merdanelerde yüzey sıcaklık dağılımının çok daha dengeli olduğu ancak çıkış kenarına doğru sıcaklıkların bir miktar arttığ1 gözlenmiştir. $\mathrm{Bu}$ durumun engellenmesi için kullanılan DegS modelde, düşük iş akışkanı debilerinde hedeflenen dengelenme sağlansa da akışkan debisinin yüksek değerleri için bahsedilen davranış terse dönmüş, çıkış kenarına doğru sıcaklıkların artmak yerine azaldığı görülmüş ve yüzey sicaklık dengesi bozulmuştur. $\mathrm{Bu}$ duruma hatve azalmasi nedeniyle artan iş akışkanı hızına bağlı hedeflenenden daha fazla artan 1S1 taşınım katsayısının neden olduğu düşünülmektedir.

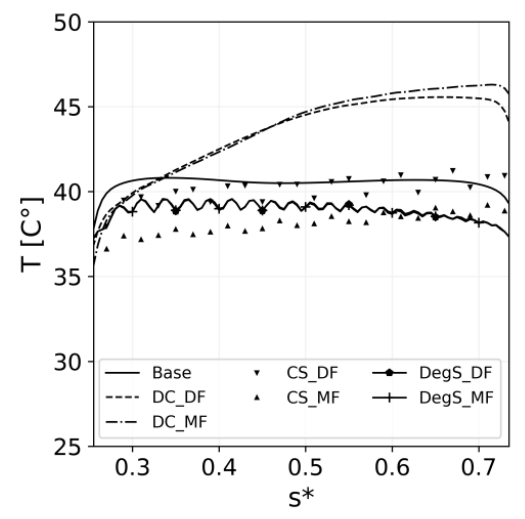

a)

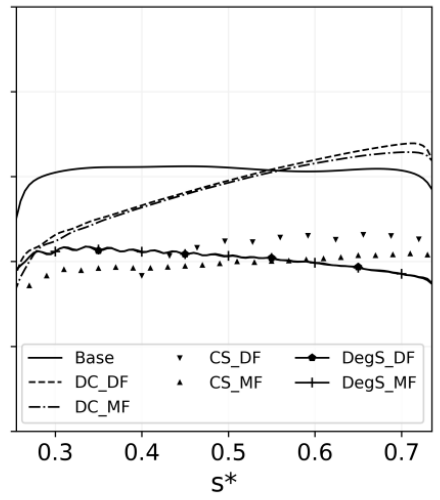

b)

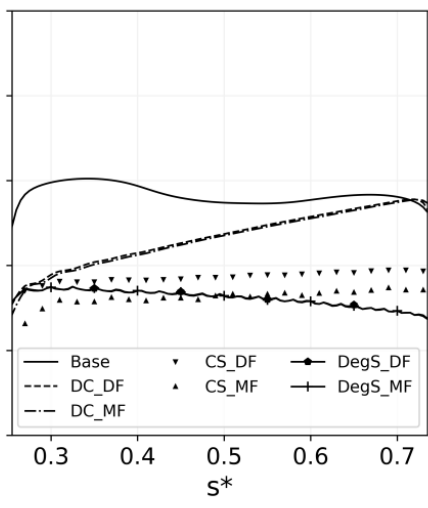

c)

Şekil 6: İş akışkanı debileri a) $100 \mathrm{~kg} / \mathrm{min}$, b) $200 \mathrm{~kg} / \mathrm{min}$ ve c) $300 \mathrm{~kg} / \mathrm{min}$ durumları için merdane yüzey sıcaklıklarının boyutsuz konum $\left(\mathrm{s}^{*}\right)$ ile değişimi 


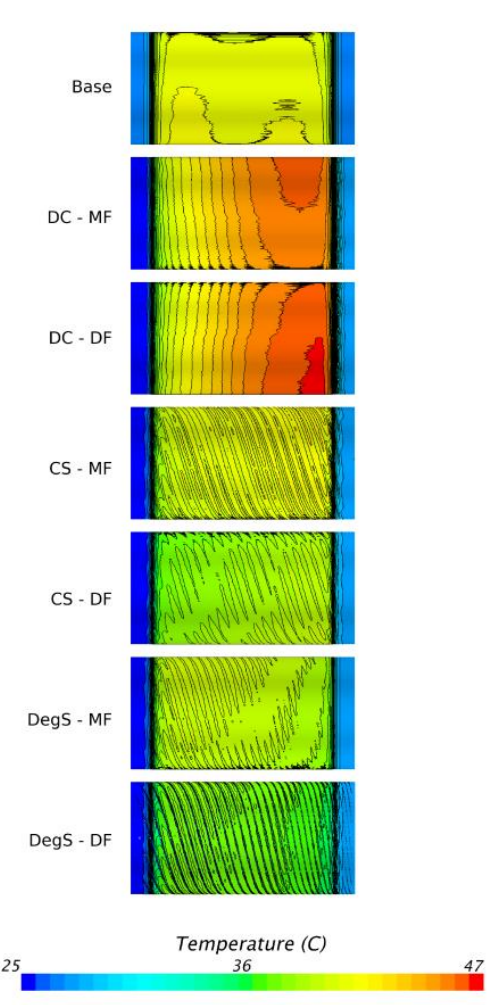

a)
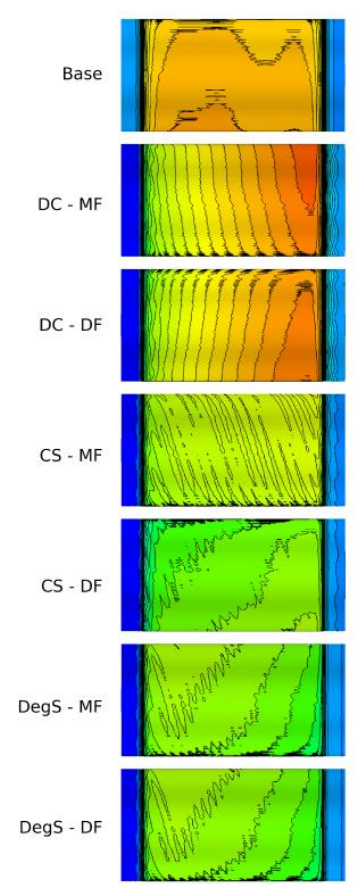

Temperature (C)

b)

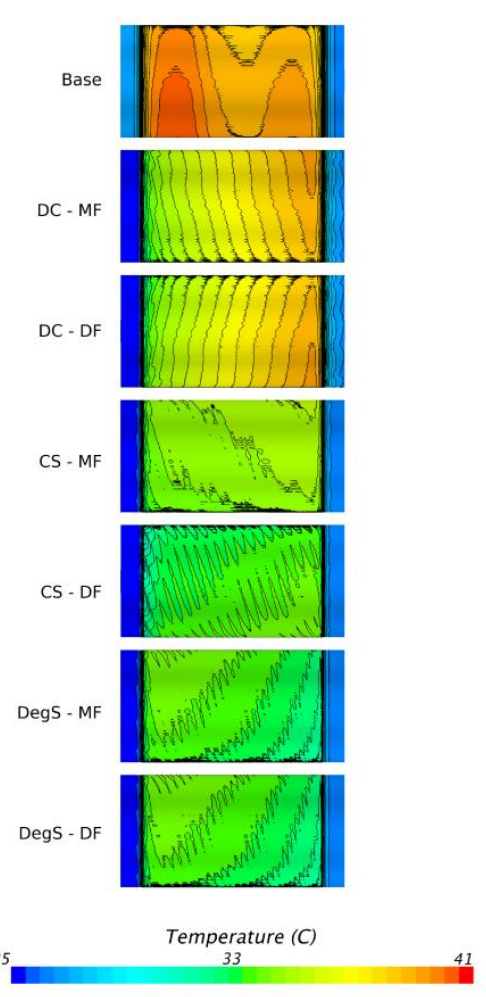

c)

Şekil 7: Farklı merdane modelleri için yüzey sıcaklık dağılımları (a- 100 kg/min, b- 200 kg/min ve c- 300 kg/min),

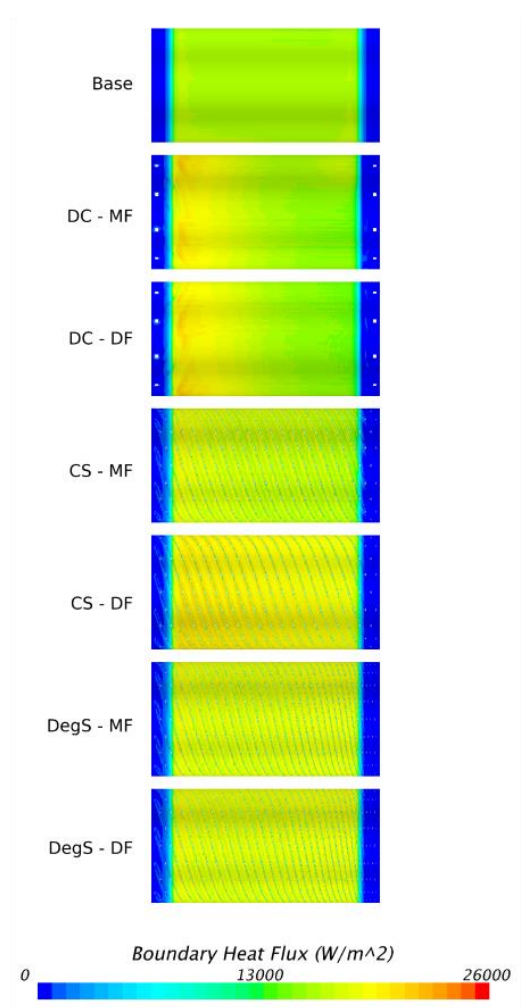

a)

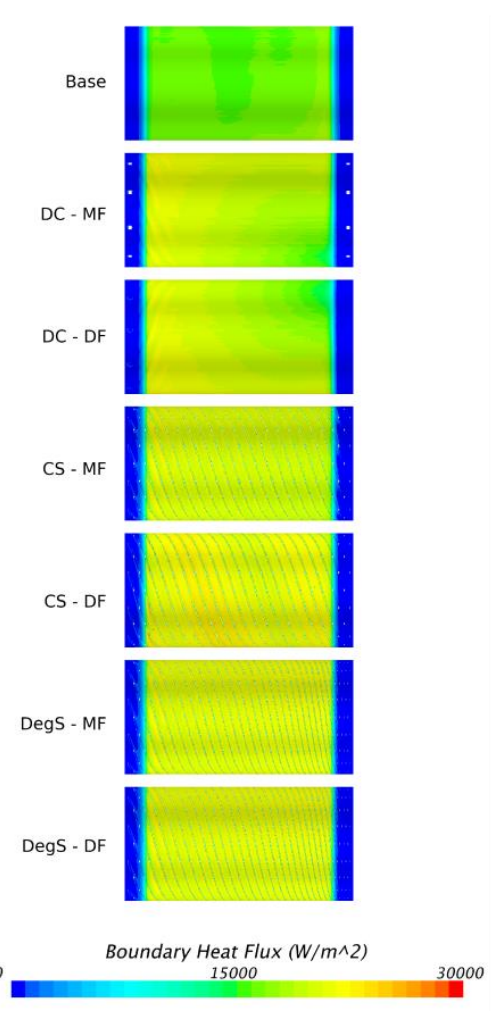

b)

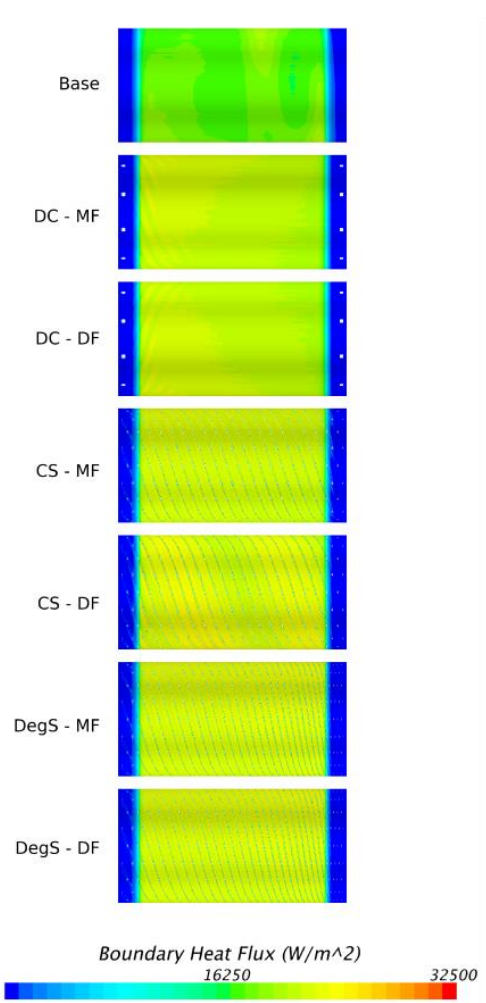

c)

Şekil 8: Farklı merdane modelleri için yüzey 1sı akısı (a- 100 kg/min, b- 200 kg/min ve c- 300 kg/min) 
Giriş kısmında bahsedildiği üzere, 1S1 transfer merdanelerinde üretilen malzemenin kalitesini belirleyen faktörlerden birisi de malzemeden tüm yüzey boyunca eşit miktar 1sı çekerek 1sıl gerilmelerin önüne geçmektir(Kumpinsky, 1993). İş akışkanı tarafından merdane yüzeyinden emilen 1sı akısı değerlerinin farklı merdane modelleri için değişimi Şekil 8'de görülmektedir. Şekilden de anlaşılacağ1 üzere, 1s1 akıs1 dağılımlarındaki değişim, Şekil 7'de incelenen sicaklık dağılımlarındaki değişim ile oldukça benzerdir. Isı akısı ve sıcaklık dağılımlarının bağlantılı olduğu ve 1sı akısı değişiminin yüzey sıcaklıklarını belirlediği düşünülebilir. Isı akısının dengesinin en az olduğu modeller, sıcaklık dağılımlarındaki davranışa paralel olarak DC modeller olmuştur. Isı akısı dağılımında, sabit hatveli spirallerin eklenmesi ile iyileşme sağlanmış, ancak sabit kanal içi hızlar ve taşınım katsayıları nedeniyle çıkış kenarına doğru 1sı akısında azalma görülmüştür. Hareketi boyunca sıcaklığı artan iş akışkanının çıkış kenarına doğru hızının ve dolayısıyla ısı transfer katsayısının artmasını sağlayan DegS model, düşük debiler için daha uniform bir 1s1 akısı dağılımı sağlamıştır. Ancak yüksek akışkan debilerinde 1S1 transfer davranışındaki artış çıkış kenarına yaklaştıkça 1 sı akısının hedeflenenden daha fazla artmasına neden olmuştur.

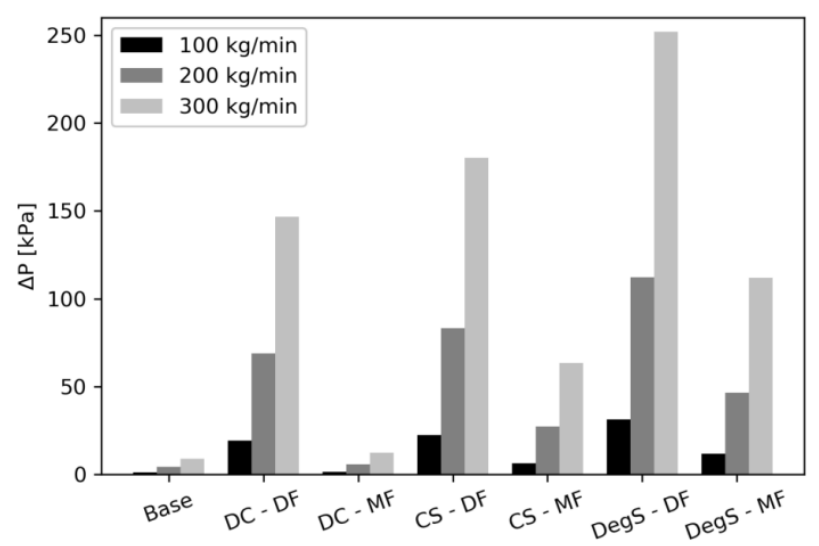

Şekil 9: Merdanelerde basınç düşüşleri

Merdanelerde 1S1 transfer miktarları ve yüzey sıcaklık dağılımları kadar önemli olan bir diğer akış kaynaklı parametre ise basınç düşüşüdür. İş akışkanının merdane giriş ve çıkış noktaları arasındaki basınç düşüşü, sistemin enerji verimliliğinin de bir ölçüsüdür. Şekil 9'da farklı iş akışkanı debilerinde analiz edilen merdanelerdeki basınç düşüşleri verilmiştir. Isı transfer performansıdiğer modellere göre daha başarısız olsa da, "Base" model en düşük basınç düşüşüne neden olmaktadır. Diğer kanal tipleri içerisinde en yüksek basınç düşüşü "DegS" modelde gözlenmiştir. Daralan spiral kanallardaki hız artışı ve sonucunda oluşan sürtünme kaybının "DegS" modeldeki yüksek basınç düşüşüne neden olduğu düşünülmektedir. Tüm modeller için basınç düşüşü değerleri akışkan debisi ile artmaktadır. Bunun yanında, iş akışkanı hareketinin DF şeklinde sağlandığ modellerin MF modellere kıyasla daha yüksek basınç düşüşüne neden olduğu görülmektedir. "DF" modeldeki merdanelerde iş akışkanının eş merkezli kanallar vasıtasıyla giriş yönünde merdaneyi terk etmesi, buna bağlı olarak basınç düşüşünü arttıran temel neden olduğu düşünülmektedir.

\section{Sonuç}

Bu çalışmada, aynı temel boyutlara ve farklı içyapıya sahip 7 adet 1S1 transfer merdanesi modeli hesaplamalı akışkanlar dinamiği yardımıyla sayısal olarak incelenmiştir. Merdane modelleri, iş akışkanının hareket ettiği kanalların yapısı yönünden farklılıklar içermektedir. Merdane modellerine ait sayısal sonuçlar farklı akışkan debileri için tekrarlanmış ve sonuçlar karşılaştırmalı olarak sunulmuştur.

Is1 transfer merdanelerinin kullanıldı $\breve{g}_{1}$ operasyonlarda, üretilen malzemenin kalitesi açısından uniform bir yüzey sıcaklık dağılımı elde etmek ve malzemede 1sıl gerilmelere sebep olmamak önemli bir husustur. Çalışma sonuçları incelendiğinde;

1. İş akışkanı kanallarına sahip olmayan merdane modelinin 1sıl performansının düşük olduğu ve akışkan debisinin artmasıyla birlikte merdane yüzeyindeki uniform sıcaklık dağılımını da kaybettiği görülmüştür.

2. Merdane iç yapısına ısıl performansı arttırmak için eklenen farklı akış kanalı yapılarının üretilen malzemeden çekilen 1sı yönünde iyileşme sağladığı, ancak yüzey sıcaklığı yönünden akış geometrisinden çok etkilendiği gözlenmiştir.

3. Merdane yapısına eklenen kanalların spiral yapısı, daha dengeli bir sıcaklık dağılımı elde edilmesini sağlamıştır. Ancak sabit hatveli spirallerde akışkanın merdane boyunca ısındığı ve 1Sı transferinin çıkışa doğru azaldığı anlaşılmıştır.

4. Azalan hatveli spiral kanallı merdane modeli düşük akışkan debilerinde başarılı sonuçlar verse de akışkan debisi arttıkça 1sı transferinin hedeflenenden daha fazla gerçekleşmesine ve merdane yüzeyinde yerel sıcaklık azalmalarına neden olmuştur.

5. Azalan hatveli spiral kanallar içeren modelin hatve yapısının, kullanılacak operasyon şartlarına göre optimize edilmesi gerektiği anlaşılmıştır. Çalışmada ayrıca farklı merdane modelleri için hidrolik basınç düşüşleri de incelenmiş, 1S1 transferinde bir model hariç önemli değişim yaratmayan çift akışlı çalışma yapısının basınç kaybında önemli artışlara neden olduğu gözlenmiştir.

Yapılan çalışmada 1S1 transfer merdanelerinin 1 sıl performanslarının en önemli noktası olan iç yapılarının sistemli geometrik varyasyonları elde edilmiş ve bu geometrik değişikliklerin 1 sıl perfoması ne şekilde etkilediği tartışılmıştır. $\mathrm{Bu}$ geometrik varyasyonlarda kullanılan bazı paremetreler bu çalışmanın geometrik konseptini genişletecek şekilde başka bir çalışmada azalan hatveli spiral yapıların geometrik parametreleri daha geniş bir ölçekte ele alınarak irdelenmesinin çalışmanın devamlılığı için faydalı olacağı söylenebilir.

\section{Kaynakça}

Boache P. J., Perspective: A method for uniform reporting of grid refinement studies, J. Fluids Eng. Trans. ASME, c. 116, say1 3, ss. 405-413, 1994.

Celik I. B., Ghia U., Roache P. J., Freitas C. J., Coleman H. ve Raad P. E., Procedure for estimation and reporting of uncertainty due to discretization in CFD applications, J. FluidsEng. Trans. ASME, c. 130, say1 7, ss. 0780011$0780014,2008$. 
Cotrell D. L., Flow between a cylinder and a rotating coaxial cylinder, axisymmetric shaft with axially-periodic radius variation, orscrew, University of Illinois at UrbanaChampaign, 2003.

Devisme S., Haudin J. M., Agassant J. F., Rauline D. ve Chopinez F., Numerical simulation of extrusion coating, Int. Polym. Process., c. 22, say1 1, ss. 90-104, 2007.

Fénot M., Bertin Y., Dorignac E. ve Lalizel G., A review of heat transfer between concentric rotating cylinders with or without axial flow, Int. J. Therm. Sci., c. 50, sayı 7, ss. 1138-1155, 2011.

Fénot M., Dorignac E., Giret A. ve Lalizel G., Convective heat transfer in the entry region of an annular channel with slotted rotating inner cylinder, Appl. Therm. Eng., c. 54, say1 1, ss. 345-358, 2013.

Funk W. H., Rotating double shell heat exchanged rummeans and method of operating same, 1957.

Huang S. ve Chun C. H., A numerical study of turbulent flow and conjugate heat transfer in concentric annuli with moving inner rod, Int. J. Heat Mass Transf., c. 46, say1 19, ss. 37073716, 2003.

Jeng T. M., Tzeng S. C. ve Lin C. H., Heat transfer enhancement of Taylor-Couette-Poiseuille flow in an annulus by mounting longitudinal ribs on the rotating inner cylinder, Int. J. Heat Mass Transf., c. 50, say1 1-2, ss. 381-390, 2007.

Jones D. P., McCann M. J., Abbott SJ, Web tension variations caused by temperature changes and slip on rollers, Proc. Elev. Int. Conf. Web Handl., ss. 65-84, 2011.

Kumpinsky E., Heat-Transfer Model Assessment of Chill Rolls for Polymer Film Extrusion, Ind. Eng. Chem. Res., c. 32, say1 11, ss. 2866-2872, 1993.

Lamberti G. ve Titomanlio G., Analysis of film casting process: The heat transfer phenomena, Chem. Eng. Process. Process Intensif., c. 44, say1 10, ss. 1117-1122, 2005.

Liu H., Chen W., Qiu S. ve Liu G., Numerical simulation of initial development of fluid flow and heat transfer in planar flow casting process, Metall. Mater. Trans. B Process Metall. Mater. Process. Sci., c. 40, say1 3, ss. 411-429, 2009.

Lockhar F. N., Heat transfer roll, 1967.

Lu Y. ve Pagilla P. R., Adaptive control of web tension in a heat transfer section of a roll-to-roll manufacturing process line, Proc. Am. Control Conf., ss. 1799-1804, 2014.

Lu Y., Pagilla P. R., Modeling Of Temperature Distribution In A Moving Web Transported Over A Heat Transfer Roller, içinde ASME 2012 5th Annual Dynamic Systems and Control Conference joint with the JSME 2012 11th Motion and Vibration Conference, 2012

Malewski T., Heating roller assembly for laminating, embossing and printing machines, 1958.

Nouri-Borujerdi A. ve Nakhchi M. E., Heat transfer enhancement in annular flow with outer grooved cylinder and rotating inner cylinder: Review and experiments, Appl. Therm. Eng., c. 120, ss. 257-268, 2017.

Pato T. G., Heat trasnfer roller having fluid circulating means there in, 1968.

Poncet S., Haddadi S. ve Viazzo S., Numerical modeling of fluid flow and heat transfer in a narrow Taylor-Couette-Poiseuille system, Int. J. Heat Fluid Flow, c. 32, say1 1, ss. 128-144, 2011.

Rahaim C. P., Oberkampf W. L., Cosner R. R. ve Dominik D. F., AIAA committee on standards for computational fluid dynamics -Status and plans, 41st Aerosp. Sci. Meet. Exhib., ss. 1-22, 2003.
Ramundo B. T., Heat exchange rolls, 1960.

Roache P. J., Verification of codes and calculations, AIAA J., c. 36, say1 5, ss. 696-702, 1998.

Shih T.H., Liou W. W., Shabbir A., Yang Z. ve Zhu J., A New Kt Eddy Viscosity Model For High: Reynolds Number Turbulent Flows, Comput. Fluids, c. 24, say1 3, ss. 227-238, 1995.

SiemensPLM, STAR-CCM+ User guide, Version 14.02.010. 2019.

Sven Barthel G. E., Oil-heated roller, 1984.

Theysohn H., Calender heating roll, 1977.

Wedel G. L., Heat transfer roll and method, 1984.

Wilcox, D. C., Turbulence Modeling for CFD, D C W Industries; 2nd Edition, 1998. 